\title{
PENGETAHUAN TERHADAP PERILAKU IBU DALAM PEMBERIAN ASI EKSKLUSIF DI KLINIK PERMATA IBU
}

\author{
${ }^{1}$ Inayatul Aini \\ ${ }^{1}$ STIKes Insan Cendekia Medika Jombang \\ ${ }^{1}$ Email : inayad4icme@gmail.com
}

\begin{abstract}
ABSTRAK
Rendahnya pengetahuan terhadap pemberian ASI Eksklusif berdampak pada perilaku ibu. Hasil studi pendahuluan terhadap $10 \mathrm{ibu}$ yang memiliki anak yang berusia 0-6 bulan terdapat $7 \mathrm{ibu}$ yang tidak memberikan ASI Eksklusif karena bekerja, sibuk dan kurang mengerti tentang ASI Eksklusif dikarenakan tidak pernah mendapatkan informasi tentang ASI Eksklusif.Tujuan penelitian ini adalah mengidentifikasi pengaruh pengetahuan terhadap perilaku ibu dalam pemberian ASI Eksklusif. Desain penelitian ini menggunakan survey variabel independennya adalah pengetahuan, variabel dependennya adalah perilaku ibu dalam pemberian ASI Eksklusif. Populasinya adalah ibu yang memiliki bayi usia 6-12 bulan di Klinik Permata Ibu sebanyak 51 orang. Sampling yang digunakan adalah simple random sampling. Data ini diambil dengan menggunakan kuesioner. Hasil penelitian terhadap 45 responden didapatkan pengetahuan ibu dalam pemberian ASI Eksklusif hampir setengahnya mempunyai pengetahuan kurang, perilaku ibu memberikan ASI Eksklusif sebagian besar pasif. Penelitian ini menggunakan uji spearman rho dengan nilai $\mathrm{P}<0,05$. Hasil uji statistik diperoleh $\mathrm{P}=0,041<0,05$. Kesimpulannya adalah ada pengaruh pengetahuan terhadap perilaku ibu dalam pemberian ASI Eksklusif dengan nilai signifikasi 0,041 .
\end{abstract}

Kata Kunci : Pengetahuan, perilaku, ASI Eksklusif.

\section{KNOWLEDGE OF MOTHER BEHAVIOR IN EXCLUSIVE ASKING IN MOM'S PERMATA CLINIC}

The lack of knowledge of exclusive breastfeeding has an impact on maternal behavior. The results of a preliminary study of 10 mothers who have children aged 0-6 months there are 7 mothers who do not give exclusive breastfeeding because of work, busy and do not understand about exclusive breastfeeding because they never get information about exclusive breastfeeding. The purpose of this study is to identify the effect of knowledge on maternal behavior in exclusive breastfeeding. The design of this study uses a survey of the independent variable knowledge, the dependent variable is the mother's behavior in exclusive breastfeeding. The population is 51 mothers who have babies aged 6-12 months at Permata Ibu Clinic. The sampling used is simple random sampling. This data was taken using a questionnaire. The results of the study of 45 respondents found knowledge of mothers in exclusive breastfeeding nearly half had less knowledge, the behavior of mothers giving 
exclusive breastfeeding was mostly passive. This study uses the Spearman rho test with a $P$ value <0.05. Statistical test results obtained $P=0.041<0.05$. The conclusion is there is an influence of knowledge on maternal behavior in exclusive breastfeeding with a significance value of 0.041.

Keywords: Knowledge, behavior, exclusive breastfeeding.

\section{PEDAHULUAN}

Air Susu Ibu (ASI) mengandung zatzat esensial yang menjamin kecukupan gizi bayi serta bermanfaat untuk meningkatkan daya tahan tubuhnya. ASI Eksklusif adalah pemberian ASI saja tanpa makanan dan minuman lain sampai bayi berusia 6 bulan, kemudian pemberian ASI harus tetap dilanjutkan sampai bayi berusia 2 (dua) tahun walaupun bayi sudah makan (Depkes RI, 2013).

Banyak faktor yang mempengaruhi rendahnya jumlah ibu yang memberikan ASI Eksklusif antara lain pengetahuan ibu tentang pemberian ASI Eksklusif masih rendah dan banyaknya ibu yang mempunyai pekerjaan di luar rumah, selain itu banyak ibu-ibu yang tidak tertarik untuk menambah wawasan atau mencari informasi tentang ASI Eksklusif di media cetak dan media elektronik. Meskipun menyusui dan ASI sangat bermanfaat, namun pelaksanaan pemberian ASI Eksklusif belum sepenuhnya dilakukan, diperkirakan $85 \%$ ibu-ibu di dunia tidak memberikan ASI secara optimal. Dari hasil penelitian United Nation Child's Fund (UNICEF) dari tahun 2005 hingga 2011 didapati bayi Indonesia yang mendapat ASI Eksklusif selama 6 bulan pertama ialah sebanyak 32\% dan didapati 50\% anak diberikan ASI Eksklusif sehingga usia 23 bulan (UNICEF, 2011).

Berdasarkan data dari Sentra laktasi Indonesia mencatat bahwa hasil dari
Survei Demografi dan Kesehatan Indonesia 2007-2010, hanya 48\% ibu yang memberikan ASI eksklusif. Di Indonesia, rata-rata ibu memberikan ASI eksklusif hanya 2 bulan, sementara pemberian susu formula meningkat 3 kali lipat. Hasil dari DepKes RI tahun 2013 menyatakan bahwa hanya 48,6\% bayi di Indonesia mendapatkan ASI Eksklusif hingga usia 6 bulan.

Berdasarkan studi pendahuluan yang dilakukan peneliti pada tanggal 26 Oktober 2017 di Klinik Permata Ibu mencatat bahwa dari 10 ibu yang memiliki anak yang berusia 0-6 bulan terdapat $7 \mathrm{ibu}$ yang tidak memberikan ASI Eksklusif di karenakan bekerja, sibuk dan kurang mengerti tentang ASI Eksklusif dikarenakan tidak pernah mendapatkan informasi tentang ASI Eksklusif. Sedangkan 3 ibu yang memberikan ASI Eksklusif pada anaknya sudah tahu dan paham bahwa ASI Eksklusif sangat penting bagi pertumbuhan dan perkembangan bayinya.

Kecenderungan penurunan dalam penggunaan ASI, diantaranya adalah pengetahuan ibu tentang pemberian ASI Eksklusif masih rendah, belum maksimalnya kegiatan edukasi, sosialisasi, advokasi, dan kampanye terkait pemberian ASI Eksklusif, adanya iklan yang menyesatkan ibu-ibu yang bekerja dan memberikan susu botol sebagai suatu simbol bagi kehidupan tingkat sosial yang lebih tinggi, banyaknya ibu yang mempunyai pekerjaan di luar rumah, kurang mendapatkan informasi tentang ASI eksklusif, dan belum semua rumah 
sakit melaksanakan 10 Langkah Menuju Keberhasilan Menyusui (LMKM) (Depkes RI, 2013).

Dampak jika ibu yang tidak memberikan ASI eksklusif pada bayinya, bayi tidak mendapatkan antibodi sehingga mudah sakit. Menurut penelitian, anak-anak yang tidak diberi ASI mempunyai IQ (Intellectual Quotient) lebih rendah 7 8 poin dibandingkan dengan anak-anak yang diberi ASI secara eksklusif. Sedang bagi bayi yang mendapatkan ASI eksklusif tidak mudah terkena infeksi pencernaan dan alergi, merangsang kecerdasan, mendapatkan vaksin alami, menyehatkan jantung, mencegah kegemukan dan gizi prima. Dampak pada ibu yang memberikan ASI eksklusif pada bayinya bagi ibu ekonomis dan praktis, badan langsing, pemulihan rahim sempurna, tidak mudah perdarahan, tidak mudah terkena kanker payudara dan tidak mudah stres.

Dari fenomena di atas maka upaya yang perlu dilakukan untuk meningkatkan cakupan pemberian ASI Eksklusif adalah dengan memberikan penyuluhan pada ibu hamil dan ibu menyusui tentang pemberian ASI eksklusif pada bayinya. Pemberian ASI Eksklusif merupakan cara pemberian makanan yang sangat tepat dan kesempatan terbaik bagi kelangsungan hidup bayi di usia 6 bulan, dan melanjutkan pemberian ASI sampai umur 2 tahun (Harnowo, 2012).

Berdasarkan uraian tersebut penulis tertarik untuk meneliti tentang pengaruh pengetahuan terhadap perilaku ibu dalam pemberian ASI Eksklusif di Klinik Permata Ibu.

\section{Konsep Dasar Perilaku}

Perilaku adalah suatu kegiatan atau aktivitas organisme (makhluk hidup) yang bersangkutan. Jadi, perilaku manusia pada hakikatnya adalah tindakan atau aktivitas dari manusia itu sendiri yang mempunyai bentangan yang sangat luas, mencakup: berjalan, berbicara, menangis, tertawa, bekerja, menulis, membaca, bereaksi, berpakaian, dan sebagainya (Notoatmodjo, 2007).

Menurut Skinner (Notoatmodjo, 2007) menyatakan bahwa prosedur pembentukan perilaku terjadi dalam tingkatan tahapan, yaitu :

a. Melakukan identifikasi tentang halhal yang merupakan penguat yang akan dibentuk.

b. Melakukan analisis untuk mengidentifikasi komponen-komponen kecil yang membentuk perilaku yang dikehendaki.

c. Menggunakan secara urut komponen-komponen itu sebagai tujuan sementara, mengidentifikasi reinforce atau hadiah-hadiah untuk masing-masing komponen tersebut.

d. Melakukan pembentukan perilaku dengan menggunakan urutan komponen yang telah tersusun.

Menurut Lawrence Green bahwa perilaku manusian berangkat dari tingkat kesehatan dimana kesehatan ini dipengaruhi oleh 2 faktor pokok, yaitu faktor perilaku (behavior causes)dan faktor diluar perilaku (non behavior causes). Selanjutnya perilaku itu sendiri terbentuk dari 3 faktor, yaitu :

a) Faktor predisposisi : yang terwujud dalam pengetahuan, sikap, kepercayaan keyakinan dan nilai-nilai.

b) Faktor pendukung : yang terwujud dalam dalam lingkungan fisik, tersedia atau tidak tersedianya

fasilitas-fasilitas atau sarana-sarana kesehatan, misalnya : Puskesmas, obatobatan, alat-alat kontrasepsi, jamban. 
c) Faktor pendorong : yang terwujud dalam sikap dan perilaku-perilaku petugas kesehatan atau petugas lainnya yang merupakan kelompok retefensi dari perilaku masyarakat.

\section{Konsep Dasar Pengetahuan}

Pengetahuan merupakan hasil dari "Tahu" dan terjadi setelah seseorang melakukan penginderaan terhadap sesuatu obyek. Penginderaan terjadi melalui panca indera yaitu:penglihatan, pendengaran, penciuman rasa dan raba. Namun sebagian besar pengetahuan seseorang didapat melalui panca indera mata dan telinga. Pengetahuan atau kognitif merupakan domain yang sangat penting untuk terbentuknya perilaku seseorang (Notoatmodjo, 2007).

Pengetahuan atau kognitif merupakan domain yang sangat penting untuk terbentuknya perilaku seseorang (over behavior) pengetahuan yang tercakup dalam domain kognitif mempunyai 6 tingkatan yaitu:

Know (Tahu)

Yaitu mengingat, menghafal suatu materi yang telah dipelajari sebelumnya, ini merupakan tingkat pengetahuan yang paling rendah.

Comprehension (Pemahaman)

Yaitu suatu kemampuan untuk menjelaskan atau menginterprestasikan secara benar tentang obyek yang diketahui dan dapat diinterpretasi dengan benar.

\section{Application (Penerapan)}

Yaitu kemampuan untuk menggunakan konsep, prinsip dan prosedur materi yang telah dipelajari pada waktu, situasi atau kondisi sesungguhnya.

\section{Analysis (Analisis)}

Yaitu kemampuan untuk menjabarkan materi atau obyek dalam bentuk komponen-komponen. Hal ini dapat dilihat dari penggunaan kata-kata kerja, dapat menggambarkan / membuat bagan, membedakan atau memisahkan, mengelompokkan dan lain sebagainya.

\section{Synthesis (Sintesis)}

Yaitu kemampuan untuk melakukan/menghubungkan bagianbagian kedalam satu bentuk keselarasan yang baru dengan kata lain. Sintesis adalah kemampuan untuk menyusun formulir baru dengan formasi yang ada.

Evaluasi

Evaluasi ini berkaitan dengan kemampuan untuk melakukan atau menghubungkan bagian-bagian didalam suatu bentuk keselarasan yang baru dengan kata lain evaluasi adalah kemampuan untuk menilai dan menyusun formulir dari formulaformula yang ada.

Penilaian pengetahuan pada masingmasing tingkat pengetahuan dapat dilakukan dengan skoring yaitu :

$\begin{array}{ll}\text { Baik } & \text { : nilai } 76-100 \% \\ \text { Cukup } & \text { : nilai } 56-75 \% \\ \text { Kurang } & \text { : nilai }<56 \%\end{array}$

(Nursalam, 2008)

\section{Konsep Ibu}

Ibu adalah orang tua perempuan seorang anak, baik melalui hubungan biologis maupun sosial. Umumnya, ibu memiliki peranan yang sangat penting dalam membesarkan anak, dan panggilan ibu dapat diberikan untuk perempuan yang bukan orang tua kandung (biologis) dari seseorang yang mengisi peranan ini. Contohnya adalah pada orang tua angkat (karena adopsi) atau ibu tiri (istri ayah biologis anak)

\section{Konsep ASI Eksklusif}

ASI adalah suatu emulsi lemak dalam larutan protein, lactose dan garam 
organik yang disekresi oleh kedua belah kelenjar payudara ibu sebagai makanan utama bagi bayi (Taufan, 2011).

\section{Macam ASI Menurut Stadium \\ Laktasi}

a. Kolostrum

- Merupakan cairan yang pertama kali di sekresi oleh kelenjar payudara, mengandung tissue debris dan residual material yang terdapat dalam di alveoli dan duktus dari kelenjar payudara sebelum dan sesudah masa puerpurium.

- Merupakan cairan viscous kental dengan warna kekuningan, lebih kuning dibandingkan dengan susu matur.

- Lebih banyak mengandung protein dibanding dengan ASI yang matur tetapi berlainan dengan ASI matur pada kolostrum protein yang utama adalah globulin (gamma globulin).

- Lebih banyak mengandung antiodi dibandingkan dengan ASI yang matur, dapat memberikan perlindungan bagi bayi sampai umur 6 bulan.

- Terdapat tripsin inhibitor, sehingga hidrolisis protein didalam usus bayi menjadi kurang sempurna. Hal ini akan lebih banyak menambah kadar antibodi pada bayi.

- Volume berkisar 150 - 300 ml/24 jam.

b. Air Susu Transisi/ Peralihan
- Merupakan ASI peralihan dari kolostrum sampai ASI yang matur.

- Disekresi dari hari ke-4 sampai hari ke-10 dari masa laktasi, tetapi ada pula pendapat yang mengatakan bahwa ASI matur baru terjadi pada minggu ketiga sampai minggu kelima.

- Kadar protein makin merendah sedangkan kadar karbohidrat dan lemak makin meningkat.

- Jumlah volume akan makin meningkat.

\section{c. Air Susu Matur}

- Merupakan ASI yang dikeluarkan pada hari ke-10 dan seharusnya, komposisi relatif konstan (adapula yang menyatakan bahwa komposisi ASI relatif baru mulai minggu ke-3 sampai mingguke -5)

Pada ibu yang sehat dimana produksi ASI cukup, ASI ini merupakan makanan yang paling baik dan cukup untuk bayi sampai umur 6 bulan

Merupakan suatu cairan bewarna putih kekuningan yang diakibatkan warna dari garam cacasainat, riboflavin dan karoten yang terdapat di dalamnya.

Terdapat anti-microbial faktor antara lain :

a) Antibodi terhadap bakteri dan virus,

b) Sel (fagosit granulosit dan makrofit dan limsofit tipe T),

c) Enzim (lisozim, laktoperoksidose, lipase, katalase, fosfatase, amylase fosfo diestarase, askalin fosfotase),

d) Protein (laktoferin ,B12 dinding protein),

e) Resistan faktor terhadap stafilokokus,

f) Komplemen ,

g) Interferion producing cell, 
h) Sifat biokimia yang khas, kapasitas buffer yang rendah dan adanya faktor bifidus,

i) Hormon.

j) Laktoferin merupakan suatu iron dinding protein yang bersifat bakteriostatik kuat terhadap Escherichia dan juga menghambat pertumbuhan Candida albican.

k) Laktobasilus bifidus merupakan koloni kuman yang menyebabkan memetabolisis laktoba menjadi asam laktat yang menyebabkan rendahnya $\mathrm{pH}$ sehingga pertumbuhan kuman patogen akan dihambat.

1) Immunoglobulin memberikan mekanisme pertahanan yang efektif terhadap bakteri dan virus (terutama Ig A) dan bila bergabung dengan komplemen ini adalah suatu antibacterial non spesifik yang mengatur pertumbuhan flora usus.

m)Faktor leukosit dan $\mathrm{pH}$ ASI mempunyai pengaruh mencegah pertumbuhan kuman patogen efek bakteriostatis dicapai pada $\mathrm{pH}$ sekitar 7,20 (Taufan, 2011).

\section{Konsep Pengaruh Pengetahuan Terhadap Perilaku Ibu Dalam Pemberian ASI Eksklusif}

Pengetahuan merupakan hasil dari "Tahu" dan terjadi setelah seseorang melakukan penginderaan terhadap sesuatu obyek. Penginderaan terjadi melalui panca indera yaitu:penglihatan, pendengaran, penciuman rasa dan raba. Namun sebagian besar pengetahuan seseorang didapat melalui panca indera mata dan telinga. Pengetahuan atau kognitif merupakan domain yang sangat penting untuk terbentuknya perilaku seseorang

Perilaku adalah suatu kegiatan atau aktivitas organisme (makhluk hidup) yang bersangkutan. Jadi, perilaku manusia pada hakikatnya adalah tindakan atau aktivitas dari manusia itu sendiri yang mempunyai bentangan yang sangat luas, mencakup: berjalan, berbicara, menangis, tertawa, bekerja, menulis, membaca, bereaksi, berpakaian, dan sebagainya.

Pengetahuan tentang ASI Eksklusif yang kurang, mempengaruhi perilaku ibu yang diakibatkan oleh masih melekatnya pengetahuan budaya lokal tentang pemberian makan pada bayi, seperti pemberian madu. Perilaku menyusui yang kurang mendukung di antaranya membuang kolostrum karena dianggap tidak bersih dan kotor,pemberian makanan/minuman sebelum ASI keluar (prelaktal), serta kurangnya rasa percaya diri ibu bahwa ASI tidak cukup untuk bayinya.

\section{METODE PENELITIAN}

Dalam penelitian ini jenis penelitian yang digunakan adalah penelitian analitik. Rancangan penelitian yang akan di gunakan adalah cross sectional yaitu jenis penelitian yang akan menekankan waktu pengukuran atau observasi data variabel independen dan dependen satu kali pada suatu saat (Nursalam, 2008).

Penelitian ini dilakukan pada tanggal 26 oktober 2017 di Klinik Permata Ibu. Populasinya semua ibu yang memiliki bayi usia 6-12 bulan di Klinik Permata Ibu sebanyak 51 orang. Pada penelitian ini sampel yang digunakan adalah sebagian dari ibu yang memiliki bayi usia 6-12 bulan. Kriteria inklusi adalah karakteristik umum subjek penelitian dari suatu populasi target dan terjangkau yang akan diteliti. (Nursalam, 2010)

Pada penelitian ini kriteria inklusi meliputi : 
a) Ibu yang memiliki bayi usia 6-12 bulan

b) Bersedia menjadi responden.

c) Sehat atau tidak dalam keadaan sakit

Dalam penelitian ini menggunakan teknik probability sampling tipe simple random sampling yakni setiap anggota atau unit dari populasi mempunyai kesempatan yang sama untuk diseleksi sebagai sampel (Notoadmodjo, 2010). Dalam penelitian ini variabel Independent dalam penelitian ini adalah pengetahuan. Dalam penelitian ini variable dependentnya adalah perilaku ibu dalam pemberian ASI Eksklusif.

Instrumen pengumpulan data berupa kuesioner dengan pengisian soal oleh ibu yang mempunyai bayi usia 0-6 bulan di Klinik Permata Ibu yang ebelumnya sudah dijelaskan teknik pengisian kuesioner terlebih dahulu oleh peneliti.

\section{HASIL}

Dari 45 kuesioner yang disebarkan peneliti, seluruhnya dapat dikembalikan $100 \%$. Hasil penelitian terdiri dari dua bagian yaitu data umum yang meliputi karakteristik umur, pendidikan, pekerjaan, dan jumlah anak. Sedangkan data khusus meliputi hasil penelitian yang dimasukkan dalam distribusi frekuensi dan interpretasi data antara variabel independen dengan dependen untuk mengetahui pengaruh antara variable independen terhadap variable dependen.

\section{Data Umum}

Data umum merupakan karateristik responden yang ada di Klinik Permata Ibu Pangkalan Bun.

1. Karateristik responden menurut umur

Tabel 1.1 Distibusi frekuensi responden berdasarkan umur di Klinik Permata Ibu Pangkalan Bun Oktober 2017

$\begin{array}{ll}\text { No } & \text { Frekuensi Persentase }\end{array}$

\begin{tabular}{cll}
$<20$ tahun & 2 & 4.4 \\
$220-30$ tahun & 22 & 48.9 \\
$3>30$ tahun & 21 & 46.7 \\
\hline Jumlah & 45 & 100
\end{tabular}


Berdasarkan tabel 1.1 menunjukkan bahwa dari 45 responden hampir setengah responden berusia 20-30 tahun sebanyak 22 orang (48.9\%).

2. Karateristik responden menurut tingkat pendidikan

Tabel 1.2 Distribusi Frekuensi Responden Berdasarkan Pendidikan di Klinik Permata Ibu Pangkalan Bun Oktober 2017

\begin{tabular}{llll}
\hline No & $\begin{array}{l}\text { Tingkat } \\
\text { Pendidikan }\end{array}$ & Frekuensi & $\begin{array}{l}\text { Persentas } \\
(\%)\end{array}$ \\
\hline 1 & SD & 1 & 2.2 \\
2 & SMP & 16 & 35.6 \\
3 & SMA & 25 & 55.6 \\
4 & Perguruan tinggi & 3 & 6.6 \\
\hline & Jumlah & 45 & 100
\end{tabular}

Sumber : Data primer, Oktober 2017

Berdasarkan tabel 1.2 menunjukkan bahwa dari 45 responden sebagian besar berpendidikan SMA sebanyak 25 orang $(55.6 \%)$.

3. Karateristik responden menurut jenis pekerjaan

Tabel 1.3 Distribusi Frekuensi Responden Berdasarkan Pekerjaan di Klinik Permata Ibu Pangkalan Bun Oktober 2017

No Pekerjaan Frekuensi e

\begin{tabular}{llll} 
& & $(\%)$ \\
\hline 1 & IRT $\quad 20$ & 44.4 \\
2 & Pegawai 9 & 20 \\
& swasta & \\
3 & Wiraswasta 10 & 22.2 \\
4 & PNS/ABRI 1 & 2.2 \\
5 & Lain-lain 5 5 & 11.1 \\
\hline & Jumlah 45 & 100
\end{tabular}

Sumber : Data primer, Oktober 2017

Berdasarkan tabel 1.3 menunjukkan bahwa dari 45 responden hampir setengahnya bekerja sebagai ibu rumah tangga sebanyak 20 orang (44.4\%).
4. Karateristik responden menurut Paritas

Tabel 1.4 Distibusi frekuensi responden berdasarkan paritas di Klinik Permata Ibu Pangkalan Bun Oktober 2017

No Paritas Frekuensi Persentase

\begin{tabular}{llll} 
& & & $(\%)$ \\
\hline 1 & Primi & 11 & 24.5 \\
2 & Multi & 33 & 73.3 \\
3 & Grande & 1 & 2.2 \\
\hline
\end{tabular}

Sumber: Data Primer, Oktober 2017

Berdasarkan tabel 1.4 menunjukkan bahwa dari 45 responden sebagian besar responden multipara sebanyak 33 orang $(73.3 \%)$.

\section{Data Khusus}

1. Pengetahuan ibu dalam pemberian ASI Eksklusif

Tabel 1.5 Distibusi frekuensi responden berdasarkan pengetahuan ibu dalam pemberian ASI Eksklusif di Klinik Permata Ibu Pangkalan Bun Oktober 2017

\begin{tabular}{llll}
\hline No & Pengetahuan & Frekuensi & $\begin{array}{l}\text { Persent } \\
\text { ase } \\
(\%)\end{array}$ \\
\hline 1 & Baik & 6 & 13.3 \\
2 & Cukup & 18 & 40 \\
3 & Kurang & 21 & 46.7 \\
\hline \hline & Jumlah & 45 & 100
\end{tabular}

Sumber: Data Primer, Oktober 2017

Berdasarkan tabel 1.5 menunjukkan bahwa dari 45 responden hampir setengahnya mempunyai pengetahuan kurang sebanyak 21 orang (46.7\%).

2. Perilaku Ibu dalam pemberian ASI Eksklusif

Tabel 1.6 Distibusi frekuensi responden berdasarkan perilaku ibu dalam pemberian ASI Eksklusif di 
Klinik Permata Ibu Pangkalan Bun Oktober 2017

No Perilaku Frekuensi

Persentase

$(\%)$

\begin{tabular}{cl}
\hline 1Aktif & 2044.4 \\
2Pasif & 2555.6 \\
\hline Jumlah & 45100
\end{tabular}

Sumber: Data Primer, Oktober 2017

Berdasarkan tabel 1.6 menunjukkan bahwa dari 45 responden sebagian besar mempunyai perilaku pasif sebanyak 25 orang $(55.6 \%)$.

3. Pengetahuan Terhadap Perilaku Ibu Dalam Pemberian ASI Eksklusif

Tabel 1.7 Distibusi frekuensi responden berdasarkan pengetahuan terhadap perilaku ibu dalam pemberian ASI Eksklusif di Klinik Permata Ibu Pangkalan Bun Oktober 2017

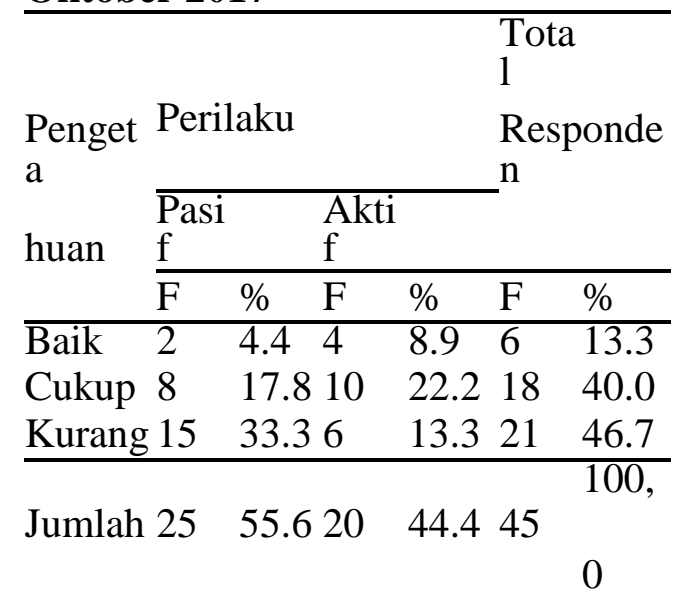

Sumber: Data Primer, Oktober 2017

Berdasarkan tabel 1.7 dapat dilihat bahwa ibu yang mempunyai pengetahuan baik sebagian kecil pasif sebanyak 2 responden (4.4\%), sedangkan yang berkategori pengetahuan baik sebagian kecil aktif sebanyak 4 responden $(8.9 \%)$ dan berkategori pengetahuan cukup sebagian kecil pasif sebanyak 8 responden $(17.8 \%)$, sedangkan pengetahuan cukup sebagian kecil aktif sebanyak 10 responden (22.2\%), serta yang berkategori pengetahuan kurang hampir setengahnya pasif sebanyak 15 responden (33.3\%), sedangkan pengetahuan kurang sebagian kecil aktif sebanyak 6 responden (13.3\%).

\section{Hasil Uji Analisis}

Tabel 1.8 Hasil Uji Statistik

Pengetahuan Terhadap Perilaku Ibu dalam Pemberian ASI Eksklusif di Klinik Permata Ibu Pangkalan Bun Oktober 2017

\begin{tabular}{|c|c|c|}
\hline $\begin{array}{l}\text { Pengeta } \\
\text { huan }\end{array}$ & $\begin{array}{l}\text { Pengetah } \\
\text { uan } \\
\text { Correl } 1.000 \\
\text { ation }\end{array}$ & $\begin{array}{l}\text { Perilak } \\
\mathrm{u} \\
.463^{* *}\end{array}$ \\
\hline \multirow{3}{*}{$\begin{array}{l}\text { Spear } \\
\text { man's } \\
\text { rho }\end{array}$} & $\begin{array}{l}\text { Coeff } \\
\text { ic } \\
\text { ient }\end{array}$ & \\
\hline & $\begin{array}{l}\text { Sig. (2- . } \\
\text { tailed } \\
\end{array}$ & .001 \\
\hline & $\begin{array}{l}\mathrm{N} \quad 45 \\
\text { Corre }\end{array}$ & 45 \\
\hline \multirow[t]{3}{*}{ Perilaku } & $\begin{array}{l}1 \quad .463^{* *} \\
\text { ation } \\
\text { Coeff } \\
\text { ic } \\
\text { ient } \\
\end{array}$ & 1.000 \\
\hline & $\begin{array}{l}\text { Sig. } \\
(2-\quad .001 \\
\text { tailed } \\
\\
\end{array}$ & . \\
\hline & $\mathrm{N} \quad 45$ & 45 \\
\hline
\end{tabular}




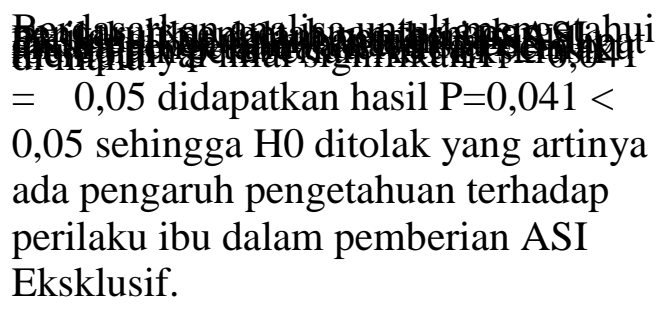

PEMBAHASAN

\section{Pengetahuan Ibu Dalam Pemberian ASI Eksklusif}

Berdasarkan tabel 1.5 dapat diketahui bahwa hampir setengahnya pengetahuan kurang sebanyak 21 responden (46.7\%). Pengetahuan yang kurang pada ibu dipengaruhi oleh bebrapa faktor yaitu umur, pendidikan, pekerjaan dan paritas. Selain faktor tersebut ada yang mempengaruhi pengetahuan diantaranya ; budaya, sosial, dan lingkungan. Dibawah ini dijelaskan faktor pengetahuan responden yang dipengaruhi oleh umur, pendidikan, pekerjaan, dan paritas.

Pengetahuan dipengaruhi oleh faktor umur. Berdasarkan tabel 1.1 tentang umur ibu dapat diketahui, hampir setengahnya responden berumur 20-30 tahun dengan jumlah 22 orang $(48.9 \%)$. Pada usia ini sebagian ibu belum cukup matang. Peran orang yang lebih tua juga sedikit berpengaruh sehingga informasi yang telah diberikan dan diterima dari tenaga kesehatan diolah lagi menurut versi orang tuanya. Hal ini didukung dengan teori Nursalam (2011) yaitu semakin cukup umur tingkat kematangan dan kekuatan seseorang akan lebih matang dalam berfikir dan bekerja.

Selain umur, pendidikan juga berpengaruh. Berdasarkan tabel 1.2 tentang pendidikan dapat diketahui, sebagian besar responden adalah lulusan SMA dengan jumlah 25 responden (55.6\%). Ragam persepsi dan pengetahuan dipengaruhi oleh sosio budaya dan tingkat pendidikannya, semakin tinggi pendidikan seseorang, maka akan semakin mudah menerima informasi, sehingga akhirnya akan semakin banyak pengetahuan yang dimilikinya (Nursalam, 2010). Tingkat pendidikan SMA merupakan tingkat pendidikan yang kurang sehingga memungkinkan responden kurang baik dalam menerima informasi tentang ASI Eksklusif.

Berdasarkan tabel 1.3 tentang pekerjaan ibu dapat diketahui, hampir setengahnya responden bekerja sebagai ibu rumah tangga dengan jumlah 20 orang (44.4\%). Pekerjaan juga berpengaruh dalam penelitian ini, dengan pekerjaan ibu bekerja sebagai ibu rumah tangga biasanya pergaulannya terbatas, karena seseorang sudah tersita waktunya untuk menyelesaikan pekerjaannya dan ibu lebih memilih memberikan susu formula kepada anaknya karena dengan memberikan susu formula kepada anaknya ibu bisa melakukan pekerjaan rumah tangga. Dengan demikian ibu yang menghabiskan waktunya hanya mengurusi urusan rumah tangga kurang mendapat pengetahuan tentang pemberian ASI Eksklusif. Hal ini sesuai dengan teori Notoatmodjo (2003) yaitu dengan adanya pekerjaan seseorang memerlukan banyak waktu. Sedangkan bekerja pada umumnya merupakan kegiatan yang menyita waktu.

Selain pekerjaan, juga dipengaruhi paritas. Berdasarkan tabel 1.4 tentang paritas dapat diketahui, sebagian besar responden multipara sebanyak 33 orang (73.3\%). Hal tersebut karena jumlah paritas dapat berpengaruh terhadap pengetahuan, dan dengan jumlah anak yang terlalu banyak dapat mengurangi waktu ibu untuk mendapatkan atau 
mencari informasi yang baik tepat dan akurat yang akan mempengaruhi pengetahuan ibu tersebut. Teori yang dinyatakan oleh Notoatmodjo (2003) bahwa paritas diperkirakan ada kaitannya dengan arah pencarian informasi tentang pengetahuan ibu menyusui dalam memberikan ASI ekslusif.

\section{Perilaku Ibu dalam Pemberian ASI Eksklusif}

Berdasarkan tabel 1.6 dapat diketahui bahwa responden sebagian besar pasif sebanyak 25 responden (55.6\%). Perilaku yang pasif pada ibu dipengaruhi oleh bebrapa faktor yaitu umur, pendidikan, pekerjaan dan paritas. Selain faktor tersebut ada yang mempengaruhi pengetahuan diantaranya ; sosial, budaya, dan kebudayaan. Dibawah ini dijelaskan faktor perilaku responden yang dipengaruhi oleh umur, pendidikan, pekerjaan, dan paritas.

Hal ini dipengaruhi oleh umur, berdasarkan tabel 1.1 tentang umur ibu dapat diketahui, hampir setengahnya responden berumur $20-30$ tahun dengan jumlah 22 orang (48.9\%). Pada usia ini sebagian ibu belum cukup matang, dengan demikian di usia ibu yang belum matang, ibu belum bisa berfikir secara logis dan benar untuk tindakan yang akan diaplikasikan pada perkembangan anaknya. Hal ini didukung dengan teori Nursalam (2010) yaitu semakin cukup umur tingkat kematangan dan kekuatan seseorang akan lebih matang dalam berfikir dan bekerja.

Selain umur, pendidikan juga berpengaruh. Berdasarkan tabel 1.2 tentang pendidikan dapat diketahui, sebagian besar responden adalah lulusan SMA dengan jumlah 25 responden (55.6\%). Seperti halnya Ibu yang lulusan SMA tapi pada jaman yang modern seperti ini ibu-ibu tersebut belum bisa menggunakan teknologi yang canggih unutk menggali informasi tentang ASI Eksklusif, sehingga dengan demikian dapat disimpulkan bahwa pengetahuan dapat mempengaruhi perilaku seseorang. Dimana semakin banyak Ibu yang mengetahui tentang ASI Eksklusif maka semakin besar pula ibu yang melakukan pemberian ASI Eksklusif kepada anaknya dengan aktif.

Berdasarkan tabel 1.3 tentang pekerjaan ibu dapat diketahui, hampir setengahnya responden bekerja sebagai ibu rumah tangga dengan jumlah 20 orang (44.4\%). Pekerjaan juga berpengaruh dalam penelitian ini, karena ibu lebih memilih memberikan susu formula kepada anaknya sehingga ibu bisa melakukan pekerjaan rumah tangga lainnya. Hal ini sesuai dengan teori Notoatmodjo (2003) yaitu dengan adanya pekerjaan seseorang memerlukan banyak waktu, sedangkan bekerja pada umumnya merupakan kegiatan yang menyita waktu.

Selain pekerjaan, juga dipengaruhi paritas. Berdasarkan tabel 1.4 tentang paritas dapat diketahui, sebagian besar responden multipara sebanyak 33 orang (73.3\%). Hal tersebut karena jumlah paritas dapat berpengaruh terhadap perilaku, dan dengan jumlah anak yang terlalu banyak dapat mengurangi waktu ibu untuk mendapatkan atau mencari informasi yang baik tepat dan akurat yang akan mempengaruhi perilaku ibu tersebut. Teori yang dinyatakan oleh Notoatmodjo (2003) bahwa paritas diperkirakan ada kaitannya dengan arah pencarian informasi tentang pengetahuan ibu menyusui dalam memberikan ASI ekslusif. 


\section{Pengaruh Pengetahuan Terhadap Perilaku Ibu Dalam Pemberian ASI Eksklusif}

Berdasarkan uji statistik dengan menggunakan uji korelasi Spearman didapatkan hasil signifikan $\mathrm{P}=0,041$ di mana $=0,05$ didapatkan hasil $\mathrm{P}=0,041$ $<0,05$ sehingga $\mathrm{H} 0$ ditolak yang artinya ada pengaruh pengetahuan terhadap perilaku ibu dalam pemberian ASI Eksklusif. Hasil penelitian pada Tabel 1.7 pengaruh pengetahuan terhadap perilaku ibu dalam pemberian ASI Eksklusif ini menunjukan bahwa yang berpengetahuan kurang cenderung pasif, berpengetahuan cukup cenderung aktif dan berpengetahuan baik cenderung aktif. Hal ini menunjukan bahwa ada pengaruh pengetahuan terhadap perilaku ibu dalam pemberian ASI Eksklusif. Menurut teori Lawrence Green, beberapa faktor yang mempengaruhi perilaku ibu salah satunya pengetahuan. Jika ibu memiliki pengetahuan yang baik tentang ASI Eksklusif maka ibu akan cenderung berperilaku aktif, begitupun sebaliknya jika ibu memiliki pengetahuan kurang maka ibu akan berperilaku pasif. Hal yang perlu dilakukan oleh para ibu adalah mengerti tentang ASI Eksklusif yang harus diberikan kepada anaknya. Lalu mengaplikasikanya sehingga perilaku ibu secara optimal akan aktif. Hal ini sesuai teori Notoatmodjo (2003) yang mengatakan bahwa apabila penerimaan perilaku melalui proses seperti ini didasari oleh pengetahuan, kesadaran dan sikap positif maka perilaku tersebut akan bersifat langgeng sebaliknya apabila perilaku itu tidak didasari oleh pengetahuan dan kesadaran maka tidak akan berlangsung lama.
Hasil penelitian ini memberikan bukti ilmiah bahwa pengetahuan sangat penting dan mempengaruhi perilaku ibu dalam pemberian ASI Eksklusif.

\section{KESIMPULAN DAN SARAN}

\section{Simpulan}

1. Pengetahuan Ibu Dalam Pemberian ASI Eksklusif di Klinik Permata Ibu hampir setengahnya berpengetahuan kurang.

2. Perilaku Ibu Dalam Pemberian ASI Eksklusif di Klinik Permata Ibu sebagian besar pasif.

3. Ada pengaruh pengetahuan terhadap perilaku ibu dalam pemberian ASI Eksklusif.

\section{Saran}

1. Bagi Responden

Diharapkan untuk meningkatkan pengetahuan tentang pemberian ASI Eksklusif yang sudah didapat melalui tenaga kesehatan, media massa, posyandu, penyuluhan atau seminar yang bertujuan untuk untuk meningkatkan derajat kesehatan anak.

2. Bagi peneliti selanjutnya

Diharapkan peneliti selanjutnya dapat melakukan penelitian terkait dengan analisis berbagai faktor yang mempengaruhi perilaku ibu dalam pemberian ASI Eksklusif.

3. Bagi Institusi Pendidikan

Diharapkan institusi pendidikan STIKes Borneo Cendekia Medika Pangkalan Bun ikut serta berperan dalam upaya meningkatkan pengetahuan masyarakat di bidang kesehatan dengan melakukan pengabdian masyarakat yang berkesinambungan kepada ibu-ibu yang memiliki anak usia 6-12 bulan.

4. Bagi Tenaga Kesehatan

Diharapkan para tenaga kesehatan lebih meningkatkan $\mathrm{KIE} /$ penyuluhan tentang 
ASI Eksklusif pada ibu hamil dan ibu menyusui.

\section{DAFTAR PUSTAKA}

Alimul, A. 2012. Metode Penelitian Kebidanan dan Teknik Analisa Data. Jakarta:Salemba Medika.

Alimul, A. 2012. Riset Keperwatan dan Teknik Penulisan Ilmiah. Jakarta:Salemba

Anton, 2004, Ibu Berikan ASI Eksklusif Baru Dua Persen, www.dinkes.go.id, (18 Maret 2014, pukul 19.00 WIB)

Azwar, S. 2008. Sikap Manusia Teori dan Pengukurannya. Yogyakarta:Pustaka Pelajar

Effendy, N. 1998. Dasar-dasar Keperawatan Kesehatan Masyarakat. Jakarta:EGC.

Effendi, F. 1998. Peran Seorang Ibu. Jakarta:Rineka Cipta.

Notoatmodjo. 2010. Metodologi Penelitian Kesehatan. Jakarta:Rineka Cipta.

Notoatmodjo. 2007. Promosi Kesehatan dan Ilmu Perilaku. Jakarta:Rineka Cipta.

Nursalam. 2011. Konsep Penerapan Metodologi Penelitian Ilmu Keperawatan. Jakarta:Salemba

Medika.

Nursalam. 2008. Konsep dan Penerapan Metodologi Penelitian Ilmu Keperawatan:Pedoman Skripsi, Tesis dan Instrumen
Penelitian. Jakarta:Salemba Medika.

Purwanti. 2004. Konsep Peneraan ASI Eksklusif Buku Saku Untuk Bidan. Jakarta: EGC

Soetjiningsih. 2004. Petunjuk ASI Untuk Tenaga Kesehatan. Jakarta: EGC

Sunaryo. 2004. Psikologi untuk Keperawatan. Jakarta: EGC.

Suparyanto. 2011. Konsep Medika http://drsuparyanto.blogspot.c om/2011/05/konsep-ibu.html diakses pada tanggal 21 Maret 2014.

Utami, R. 2008. ASI dan Manfaatnya. Jakarta:Niaga

Utami, R. 2008. Mengenal ASI Eksklusif. Jakarta:Niaga

Wawan, dkk. 2011. Teori dan Pengukuran Pengetahuan, Sikap dan Perilaku Manusia.

Yogyakarta:Nuha Medika. 